\title{
SURVEY INSTRUMENT VALIDATION RATING SCALE
}

\author{
Ryan Michael F. Oducado \\ West Visayas State University, College of Nursing \\ rmoducado@wvsu.edu.ph
}

\begin{abstract}
This paper presents a rating scale that can be used by researchers in the validation of research instruments or survey questionnaires. The statements of this survey instrument validation rating scale were adapted from the criteria for evaluating survey questionnaire set forth by Good and Scates (1972), definition of content validity given by Polit and Beck (2004; 2006) and Chavez and Canino (2005) criteria for Cultural Equivalency Model for Translating and Adapting Instruments. It also takes into account the definition of Johnson (2013) on face validation.

Face validity refers to the extent to which a test appears to measure what it is intended to measure or the test items appear, at face value, to measure what one is seeking to measure (Johnson, 2013). On the other hand, content validity refers to the sampling adequacy of items for the construct that is measured (Polit \& Beck 2004; 2006).

Good \& Scates (1972) set forth eight (8) criteria for validation of research instruments by experts are as follows: 1) is the question on the subject?, 2) is the question perfectly clear and unambiguous?, 3) does the question get at something stable? something relatively deep-seated, well-considered, non-superficial, and not ephemeral, but something which is typical of the individual or the situation?, 4) does the question pull?, 5) do the responses show a reasonable range of variation? 6) is the information obtained consistent?, 7) is the item sufficiently inclusive? And 8) is there a possibility of using an external criterion to evaluate the questionnaire?.

Meanwhile, Chávez \& Canino (2005) developed a step by step guide on the translation and adaptation of an instrument, using the latest standards for methodological approaches in cross-cultural research, in order to achieve cultural equivalency. One of the parameters is content equivalence which refers to whether the content of each item is relevant to each cultural group or population under study, that is, if it evaluates a phenomenon that occurs in and is noted as real by members of the ethnic or cultural groups (Chávez \& Canino, 2005). Chávez \& Canino (2005) recommended that a procedure similar to rational analysis, which is usually employed to obtain evidence about content validity in the development of an instrument, should be employed. That is, a panel of judges, usually composed of experts in the construct to be assessed, decides whether the instrument's items reflect the concept under study (Chávez \& Canino, 2005).
\end{abstract}




\section{SURVEY INSTRUMENT VALIDATION RATING SCALE}

Instruction: Please indicate your degree of agreement or disagreement on the statements provided below by encircling the number which corresponds to your best to your judgment.

$\mathbf{1}$ - Strongly Disagree $\quad \mathbf{2}$-Disagree $\quad \mathbf{3}$ - Undecided $\quad \mathbf{4}$-Agree $\quad \mathbf{5}$-Strongly Agree

Criteria

\begin{tabular}{|c|c|c|c|c|c|}
\hline $\begin{array}{l}\text { The items in the instrument are relevant to answer the objectives of the } \\
\text { study. }\end{array}$ & 1 & 2 & 3 & 4 & 5 \\
\hline $\begin{array}{l}\text { The items in the instrument can obtain depth to constructs being } \\
\text { measured. }\end{array}$ & 1 & 2 & 3 & 4 & 5 \\
\hline $\begin{array}{l}\text { The instrument has an appropriate sample of items for the construct } \\
\text { being measured. }\end{array}$ & 1 & 2 & 3 & 4 & 5 \\
\hline $\begin{array}{l}\text { The items and their alternatives are neither too narrow nor limited in its } \\
\text { content. }\end{array}$ & 1 & 2 & 3 & 4 & 5 \\
\hline The items in the instrument are stated clearly. & 1 & 2 & 3 & 4 & 5 \\
\hline $\begin{array}{l}\text { The items on the instrument can elicit responses which are stable, } \\
\text { definite, consistent and not conflicting. }\end{array}$ & 1 & 2 & 3 & 4 & 5 \\
\hline The terms adapted in the scale in the scale are culturally appropriate. & 1 & 2 & 3 & 4 & 5 \\
\hline The layout or format of the instrument is technically sound. & 1 & 2 & 3 & 4 & 5 \\
\hline The responses on the scale show a reasonable range of variation. & 1 & 2 & 3 & 4 & 5 \\
\hline $\begin{array}{l}\text { The instrument is not too short or long enough that the participants will } \\
\text { be able to answer it within a given time. }\end{array}$ & 1 & 2 & 3 & 4 & 5 \\
\hline $\begin{array}{l}\text { The instrument is interesting such that participants will be induced to } \\
\text { respond to it and accomplish it fully. }\end{array}$ & 1 & 2 & 3 & 4 & 5 \\
\hline $\begin{array}{l}\text { The instrument as a whole could answer the basic purpose for which it is } \\
\text { designed. }\end{array}$ & 1 & 2 & 3 & 4 & 5 \\
\hline $\begin{array}{l}\text { The instrument is culturally acceptable when administered in the local } \\
\text { setting. }\end{array}$ & 1 & 2 & 3 & 4 & 5 \\
\hline
\end{tabular}

\section{Comments and Suggestions:}




\section{References}

Chávez, L.M. \& Canino, G.C. (2005). Toolkit on translating and adapting instruments. Retrieved from: http://www.hsri.org /files/uploads/publications /PN54_Translating _and_Adapting.pdf

Good, C.V., \& Scates, D.E. (1972). In Paler-Calmorin, L., \& Calmorin, M.A. (1997). Statistics in education and the sciences. Manila, Philippines: Rex Bookstore

Johnson, E. Face validity. (2013). In: Volkmar F.R. (eds) Encyclopedia of Autism Spectrum Disorders. Springer, New York, NY

Polit, D.F., \& Beck, C.T. (2004). Nursing research: Appraising evidence for nursing practice (7th Edition). Philadelphia: Wolters Klower/Lippincott Williams \& Wilkins.

Polit, D.F., \& Beck, C.T. (2006). The content validity index: are you sure you know what's being reported? Critique and recommendations. Research in Nursing and Health, 29(5), 48997. DOI: 10.1002/nur.20147 